\title{
Mechanisms for SU5416 as a radiosensitizer of endothelial cells
}

\author{
EUN HO KIM ${ }^{1 *}$, MI-SOOK KIM ${ }^{1}$, YOUN KYOUNG JEONG ${ }^{2}$, ILSUNG CHO ${ }^{1}$, SEUNG HOON YOU ${ }^{1}$, \\ SUNG HO CHO ${ }^{1}$, HANNA LEE ${ }^{1}$, WON-GYUN JUNG ${ }^{1}$, HAG DONG KIM ${ }^{3}$ and JOON KIM ${ }^{3 *}$ \\ ${ }^{1}$ Division of Heavy Ion Clinical Research, ${ }^{2}$ Research Center for Radiotherapy, \\ Korea Institute of Radiological and Medical Sciences, Seoul 139-706; ${ }^{3}$ Laboratory of Biochemistry, \\ Division of Life Sciences, Korea University, Seoul 136-701, Republic of Korea
}

Received May 4, 2015; Accepted June 22, 2015

DOI: 10.3892/ijo.2015.3127

\begin{abstract}
Endothelial cells (ECs), that comprise the tumor vasculature, are critical targets for anticancer radiotherapy. The aim of this work was to study the mechanism by which SU5416, a known anti-angiogenesis inhibitor, modifies the radiation responses of human vascular ECs. Two human endothelial cell lines (HUVEC and 2H11) were treated with SU5416 alone, radiation alone, or a combination of both. In vitro tests were performed using colony forming assays, FACS analysis, western blotting, immunohistochemistry, migration assay, invasion assays and endothelial tube formation assays. The combination of radiation and SU5416 significantly inhibited cell survival, the repair of radiation-induced DNA damage, and induced apoptosis. It also caused cell cycle arrest, inhibited cell migration and invasion, and suppressed angiogenesis. In this study, our results first provide a scientific rationale to combine SU5416 with radiotherapy to target ECs and suggest its clinical application in combination cancer treatment with radiotherapy.
\end{abstract}

\section{Introduction}

The cell-killing action of radiotherapy is purposed not only at tumor cells but also at endothelial cells (ECs) of the tumor vasculature that provides solid tumors with blood $(1,2)$. The tumor vessel system, and in turn ECs, constitute a sensitive and critical target for tumor radiotherapy, resulting from the induction of radiation damage to the vasculature.

Correspondence to: Dr Eun Ho Kim, Division of Heavy Ion Clinical Research, Korea Institute of Radiological and Medical Sciences, 215-4 Gongneung-Dong, Nowon-Ku, Seoul 139-706, Republic of Korea E-mail: eh140149@kirams.re.kr

Professor Joon Kim, Laboratory of Biochemistry, Division of Life Sciences, Korea University, Seoul 136-701, Republic of Korea

E-mail: joonkim@korea.ac.kr

${ }^{*}$ Contributed equally

Key words: SU5416, radiosensitivity, endothelial cells, DNA damage, angiogenesis
Targeting angiogenesis is an attractive therapeutic strategy to inhibit tumor growth, particularly since this approach has less probability of resulting in the development of drug resistance. Radiation sensitization of tumors has the ability to increase local tumor control and disease-free survival (3). The combination of radiotherapy and targeted drugs with anti-angiogenic or anti-vascular effects has been verified as an important aim for improving the therapeutic efficiency in cancer treatment (4). Recently, several compounds were investigated in preclinical studies and have since started clinical cancer trials that combine anti-angiogenic agents with ionizing radiation to improve the anticancer effect of radiation (5-9). One of such candidates, SU5416, is a selective inhibitor of the tyrosine kinase activity of the vascular endothelial growth factor (VEGF) receptor Flk-1/KDR and is currently in phase III clinical trials for the treatment of advanced malignancies by decreasing vascularization and growth of various human cancers $(10,11)$. Single agent phase II clinical trials of SU5416 in patients with metastatic melanoma resulted in potential inhibitory effects on tumor vascularity (12), and an earlier study reported that the treatment reduced tumor growth and vascularization in an animal model of neuroblastoma (13). VEGF is known to be upregulated in various human tumors (1). The concept of combining anti-vascular compounds or angiogenesis inhibitors has also been widely studied for the combination of VEGF signaling inhibitors concurrently or sequentially together with radiotherapy (14-22).

In this study, we investigated the mechanism by which SU5416 increased radiation-induced antitumor and anti-angiogenic effects by using endothelial cells as a representative model of the tumor vasculature. Along with the observed inhibition of VEGF signaling, we found that combination of SU5416 with radiation therapy markedly enhanced the therapeutic efficacy in endothelial cells.

\section{Materials and methods}

Antibodies and chemicals. Anti-cyclin B, anti-cyclin A, anti-cyclin E, anti-extracellular signal-regulated kinase (ERK), anti-Akt, anti-c-Jun N-terminal kinase (JNK), anti-p38 and anti- $\beta$-actin were purchased from Santa Cruz Biotechnology, Inc. (Santa Cruz, CA, USA). Anti-cleaved PARP1 antibody, anti-cleaved caspase-3, anti-phospho-ERK, anti-phospho-Akt, anti-phospho-p38 and anti-phospho-JNK 
were purchased from Cell Signaling Technology (Danvers, MA, USA). Anti- $\gamma$-H2AX antibody was from Millipore. The angiogenesis inhibitor SU5416 was synthesized at Sugen Inc., as described previously (23). For in vitro experiments, it was dissolved in DMSO to make a $10 \mathrm{mmol} / \mathrm{l}$ stock solution and stored at $-20^{\circ} \mathrm{C}$.

Cell culture. Human umbilical vein endothelial cells (HUVECs) were maintained in endothelial cell basal medium (EGM-2) containing EGM-2 SingleQuot growth supplements (both from Cambrex) and maintained for no more than eight culture passages. The murine endothelial cell line $2 \mathrm{H} 11$ was maintained in DMEM plus $10 \%$ fetal bovine serum (FBS) in a humidified $10 \% \mathrm{CO}_{2}$ environment.

Irradiation. Cells were plated in $60-\mathrm{mm}$ dishes and incubated at $37^{\circ} \mathrm{C}$ under humidified conditions and $5 \% \mathrm{CO}_{2}$ to $70-80 \%$ confluence. Cells were irradiated with a ${ }^{137} \mathrm{Cs}$ gamma-ray source (Atomic Energy of Canada, Ltd., Ontario, ON, Canada) at a dose rate of $3.81 \mathrm{~Gy} / \mathrm{min}$.

Colony-forming assay. SU5416 ( $1 \mu \mathrm{mol} / \mathrm{l})$ was preincubated for $6 \mathrm{~h}$ before radiation exposure and then incubated for a total of $72 \mathrm{~h}$. After 14-20 days, colonies were stained with $0.4 \%$ crystal violet (Sigma, St. Louis, MO, USA). The plating efficiency (PE) represents the percentage of seeded cells that grew into colonies under the specific culture conditions of the given cell line. The survival fraction, expressed as a function of irradiation, was calculated as follows: survival fraction, colonies counted/(cells seeded x PE/100). The plating efficiency of HUVEC and $2 \mathrm{H} 11$ were $0.72 \pm 0.18$ and $0.79 \pm 0.15$. To evaluate the radio-sensitizing effects of SU5416, the ratio of radiation alone to radiation plus SU5416 was calculated as the dose (Gy) for radiation alone divided by the dose for radiation plus SU5416 at a surviving fraction of $10 \%$.

Detection of apoptotic cells by Annexin V staining. After SU5416 preincubation, radiation was added to the cells, and the cells were subsequently incubated for $48 \mathrm{~h}$. Cells were then washed with ice-cold PBS, trypsinized, and resuspended in $1 \mathrm{X}$ binding buffer $[10 \mathrm{~mm}$ HEPES/NaOH (pH 7.4), $140 \mathrm{~mm}$ $\mathrm{NaCl}$, and $\left.2.5 \mathrm{~mm} \mathrm{CaCl}_{2}\right]$ at $1 \times 10^{6}$ cells $/ \mathrm{ml}$. Aliquots $(100 \mu \mathrm{l})$ of cell solution were mixed with $5 \mu 1$ Annexin V FITC (BD Pharmingen) and $10 \mu 1$ propidium iodide (PI) stock solution (50 $\mu \mathrm{g} / \mathrm{ml}$ in PBS) by gentle vortexing, followed by 15 min incubation at room temperature in the dark. Buffer (400 $\mu 1,1 \mathrm{X})$ was added to each sample and analyzed on a FACScan flow cytometer (Becton-Dickinson, Franklin Lakes, NJ, USA). A minimum of 10,000 cells was counted for each sample, and data analysis was performed in CellQuest software (BD Biosciences).

Immunohistochemistry. Immunohistochemistry was performed to determine the nuclear distribution of $\gamma$-H2AX in individual cells. Cells were grown on chamber slides for one day prior to irradiation or SU5416 treatments. After SU5416 exposure, cells were irradiated and treated for various time-points. All treatments were performed while cells remained attached to the slides, followed by fixing with $4 \%$ paraformaldehyde and permeabilization with $0.2 \%$
Triton X-100 in PBS. Detection was performed after blocking the slides in $10 \% \mathrm{FBS} / 1 \%$ bovine serum albumin (BSA) for $1 \mathrm{~h}$ with a 1:1,000 dilution of fluorescein isothiocyanate (FITC)-labeled mouse monoclonal antibody against $\gamma$-H2AX, in the background-reducing antibody diluent (DAKO plus S3022) (both from Millipore, Billerica, MA, USA).

Western blotting. After SU5416 exposure, endothelial cells were irradiated and cultured for 1 and $24 \mathrm{~h}$. Protein from treated cells was extracted with RIPA buffer, separated by SDS-polyacrylamide gel electrophoresis (PAGE), and transferred to nitrocellulose membranes. Membranes were blocked with $1 \%(\mathrm{v} / \mathrm{v})$ nonfat dry milk in Tris-buffered saline with $0.05 \%$ Tween-20 and incubated with the indicated antibodies. Blots were reacted with primary antibodies at 1:1,000 dilutions and secondary antibodies at 1:5,000 dilutions. Immunoreactive protein bands were visualized by Enhanced Chemiluminescence (Amersham Biosciences) and scanned.

Wound healing scratch assay. Human endothelial cells were seeded onto 6-well plates (Corning) at $2.5 \times 10^{4}$ cells/well with $3 \mathrm{ml}$ of medium. At two days, the monolayers were mechanically disrupted with a sterile $200 \mu \mathrm{l}$ pipette tip. The assay was performed in duplicate and wells were photographed every $48 \mathrm{~h}$ prior to staining with $0.2 \%$ crystal violet. Cell migration was monitored using a Nikon Eclipse Ti microscope with a DS-Fil camera. The cells were counted using ImageJ software (US National Institutes of Health, Bethesda, MD, USA).

Invasion assay. The invasive ability in vitro was measured by using Transwell chambers, according to the manufacturer's protocol. Briefly, cells were seeded onto the membrane of the upper chamber of the Transwell at a concentration of $4 \times 10^{5 /} \mathrm{ml}$ in $150 \mu \mathrm{l}$ of medium and were left untreated or treated with the indicated doses of SU5416, radiation, or combine treatment for $24 \mathrm{~h}$. The medium in the upper chamber was serum-free, whereas the lower chamber medium contained $10 \%$ FBS as a source of chemo-attractants. Cells that passed through the Matrigel-coated membrane were stained with Cell Stain Solution containing crystal violet supplied in the Transwell invasion assay (Chemicon, Millipore, GA, USA) and photographed after a 24-h incubation period.

Matrigel in vitro endothelial tube formation assay. Endothelial cell tube formation was carried out on Matrigel-coated chamber slides as described (24). The results of each assay were photographed (Nikon Eclipse Ti microscope with DS-Fil camera) at x40 magnification. Tube formation was quantified by counting the number of connected cells in randomly selected fields at $\mathrm{x} 400$ magnification with a microscope, and dividing that number by the total number of cells in the same field. Tube formation was quantified by counting the number of connected cells in randomly selected fields at $\mathrm{x} 400$ magnification with a microscope, and dividing that number by the total number of cells in the same field.

Statistical analysis. All data were plotted as the mean \pm standard error of the mean (SEM). Results of colony forming assays were analyzed using paired t-test with SPSS 18.0 software (SPSS, Inc., Chicago, IL, USA). All other data were analyzed 

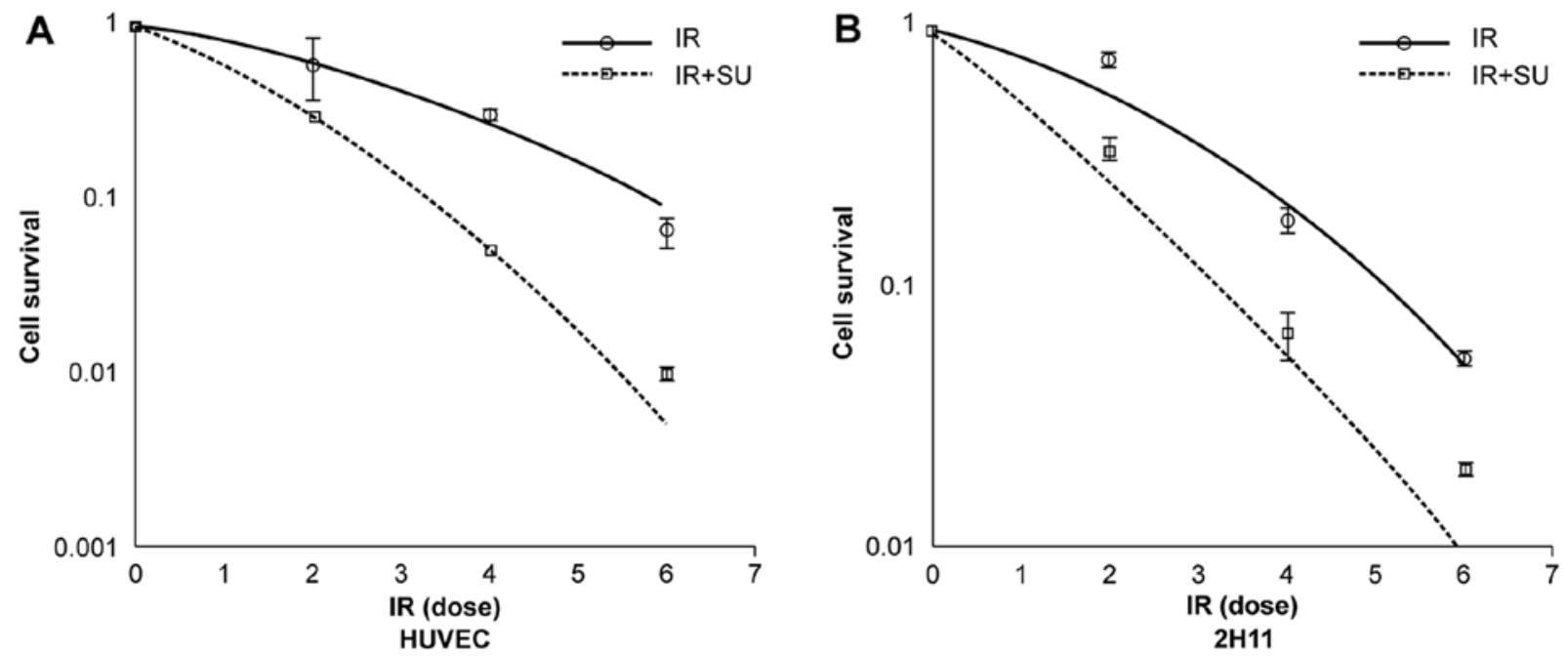

Figure 1. The radiosensitizing effects of SU5416 on endothelial cells treated with DMSO or SU5416 in combination with or without irradiation. (A and B) Radiosensitivity of human umbilical vein endothelial cells (HUVEC) and 2H11 cells treated with and without SU5416 was measured after radiation by colony forming assay. Endothelial cells (EC) cells were treated with $1 \mu \mathrm{mol} / 1 \mathrm{SU} 5416$ for $4 \mathrm{~h}$ and then washed. Subsequently, these SU5416-treated or control EC cells received 0-6 Gy radiation and colony formation was detected at day 14 after irradiation.

Table I. Fitting parameters $\alpha$ and $\beta$ for survival assay data.

\begin{tabular}{llcc}
\hline Cell type & \multicolumn{1}{c}{ Radiation type } & $\alpha\left(\mathrm{Gy}^{-1}\right)$ & $\beta\left(\mathrm{Gy}^{-1}\right)$ \\
\hline HUVEC & gamma-ray & $0.169 \pm 0.040$ & $0.039 \pm 0.012$ \\
& gamma-ray + SU5416 & $0.463 \pm 0.021$ & $0.070 \pm 0.009$ \\
$2 \mathrm{H} 11$ & gamma-ray & $0.166 \pm 0.610$ & $0.054 \pm 0.117$ \\
& gamma-ray + SU5416 & $0.626 \pm 0.610$ & $0.025 \pm 0.124$
\end{tabular}

HUVEC, human umbilical vein endothelial cells.

by parametric repeated measure one-way ANOVA followed by Tukey's-HSD test (SPSS 18.0). Statistical significance was set at $\mathrm{p}<0.05$.

\section{Results}

SU5416 radiosensitized ECs in vitro. To examine the effects of SU5416 on human endothelial cell radiosensitivity, we selected two endothelial cell lines, HUVEC and 2H11. We treated the EC cells with $1 \mu \mathrm{mol} / 1$ of SU5416 for $24 \mathrm{~h}$ prior to receiving different doses of irradiation. Using the concentration of SU5416 that showed a $20 \%$ decrease in cell survival $(1 \mu \mathrm{M})$ after a $6 \mathrm{~h}$ pretreatment (data not shown), we further investigated the effects of SU5416 pretreatment on radiation-induced cell death. The results of colony forming assay of $\gamma$-irradiated EC cells with and without SU5416 pretreatment in form of a survival curves are shown in Fig. 1. The experimental survival fraction (S/S0) data points for $\gamma$-irradiated EC cells were fitted with linear quadratic dose (D) dependent relation given by $\mathrm{S}^{\prime} \mathrm{S} 0=\exp -\left(\alpha \mathrm{D}+\beta \mathrm{D}^{2}\right)$ where $\alpha$ and $\beta$ are constants. The fitted values of $\alpha$ and $\beta$ for $\gamma$-irradiated EC cells are given in Table I. The values from the fitted curves show that there is a significant decrease in survival fraction on combined treatment of SU5416 and radiation in comparison to those cells exposed to radiation only for $90 \%$ cell killing as shown in Table II.
The REF values for $\gamma$-irradiation of SU5416 treated EC cells are shown in Table III. These data showed that SU5416 had radiosensitizing effects on ECs in vitro.

Effect of SU5416 on radiation-induced apoptosis. Ionizing radiation induces cell death after DNA damage (25). To investigate the induction of apoptosis after the combination treatment, we assessed early apoptosis by Annexin V and PI staining. Notably, $48 \mathrm{~h}$ of SU5416 and radiation exposure significantly increased the percentage of early apoptotic cells in endothelial cell lines (Fig. 2). We also examined whether SU5416 enhanced radiation cytotoxicity resulted from the further activation of the chief executioner of cell death, caspase- 3 and PARP fragmentation, in endothelial cells (Fig. 2C). Our results showed that caspase- 3 activation and PARP cleavage on treatment with SU5416 in combination with radiation was enhanced in comparison to that observed in the groups treated with SU5416 alone. We also monitored the expression of anti-apoptotic Bcl-2 protein and cell survival protein NF- $\kappa \mathrm{B}$ and found that combination treatment clearly decreased the expression of Bcl-2 and NF- $\kappa \mathrm{B}$ protein in both endothelial cell types (Fig. 2C).

Effects of SU5416 and radiation on cell cycle phase distribution. To investigate what cellular mechanisms may underlie the enhanced ionizing radiation-induced cell death following the combined treatment of SU5416, we examined the cell cycle profiles (Fig. 3A and B). Results showed that combination treatments caused alterations in distribution of cells in different phases of cell cycle in both endothelial cell lines. SubG1 phase, indicating the apoptotic population, was only moderately changed in endothelial cells following treatment with SU5416; however, the combined treatment caused accumulation of cells in subG1 phase in endothelial cells. Combination therapy caused the most accumulation of cells at G2/M phases, suggesting the highest increase of cell cycle arrest at G2/M phase in both endothelial cell lines. We also studied the expression of cell cycle regulator following 
Table II. Radiation dose required for 90\% cell killing with and without SU5416.

\begin{tabular}{lccc}
\hline Cell type & Radiation type & $\begin{array}{c}\text { Dose(Gy) for 90\% cell killing } \\
\text { without SU5416 }\end{array}$ & $\begin{array}{c}\text { Dose(Gy) for 90\% cell killing } \\
\text { with SU5416 }\end{array}$ \\
\hline HUVEC & gamma-ray & 5.84 & 3.33 \\
2 H11 & gamma-ray & 5.16 & 3.25 \\
\hline
\end{tabular}

Radiosensitivity enhancement factor, REF corresponding to $90 \%$ cell killing is calculated to quantify the radiosensitization due to SU5416 using Eq: REF, radiation dose for 90\% killing/radiation dose in presence of SU5416 for 90\% killing. HUVEC, human umbilical vein endothelial cells.
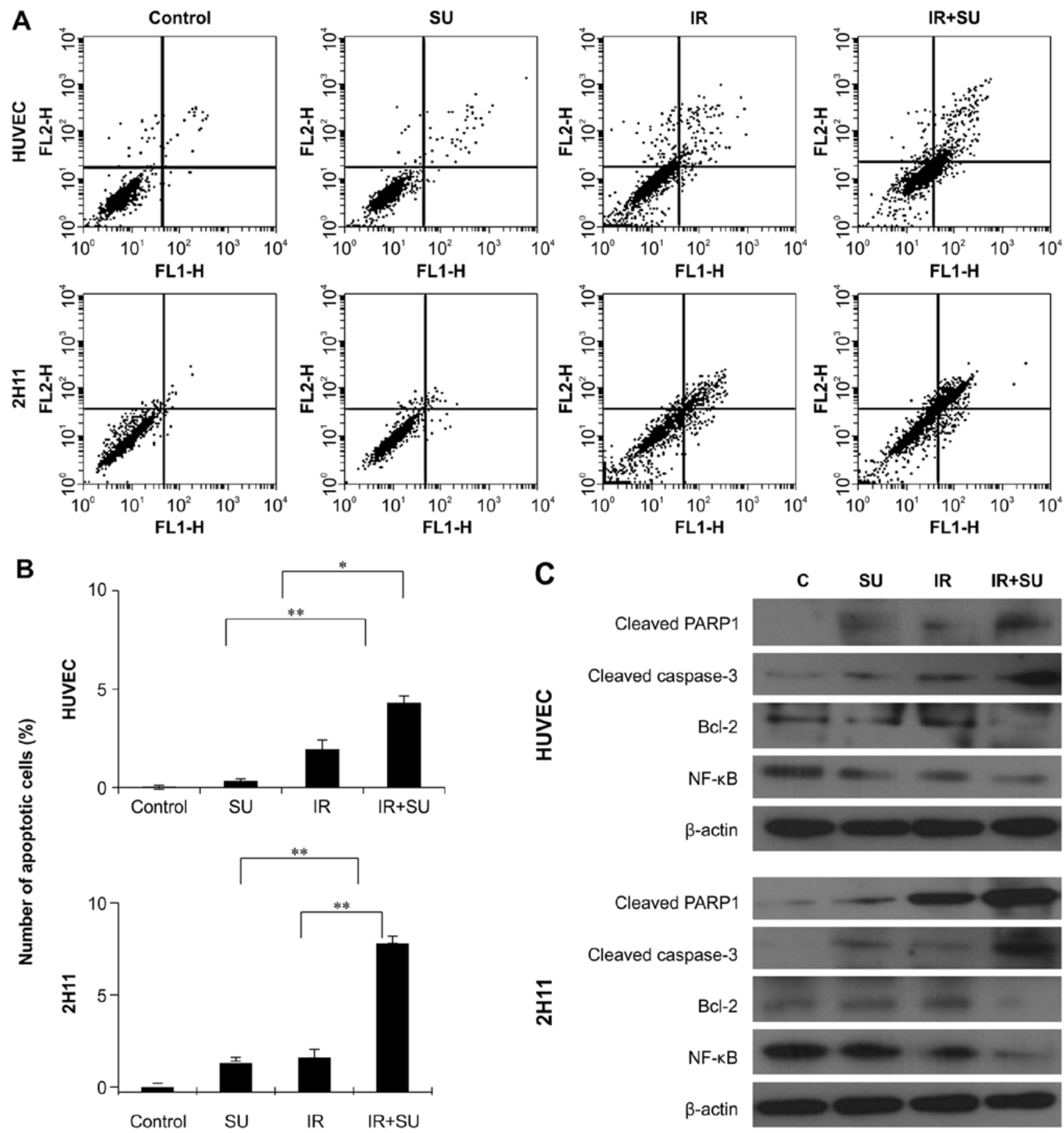

Figure 2. Effects of SU5416 and radiation on apoptosis in endothelial cells. (A and B) Human umbilical vein endothelial cells (HUVEC) and 2H11 cells were exposed to combination of SU5416 (1 $\mu \mathrm{mol} / \mathrm{l})$ and $5 \mathrm{~Gy}$ radiation. After $48 \mathrm{~h}$, cells were stained for Annexin V and PI staining and analyzed using flow cytometry. Values represent means of three experiments $\pm \mathrm{SE}$; ${ }^{*} \mathrm{p}<0.05,{ }^{* *} \mathrm{p}<0.001$. (C) Cell lysates $(30 \mu \mathrm{g}$ ) were immunoblotted (IB) with indicated antibodies. 

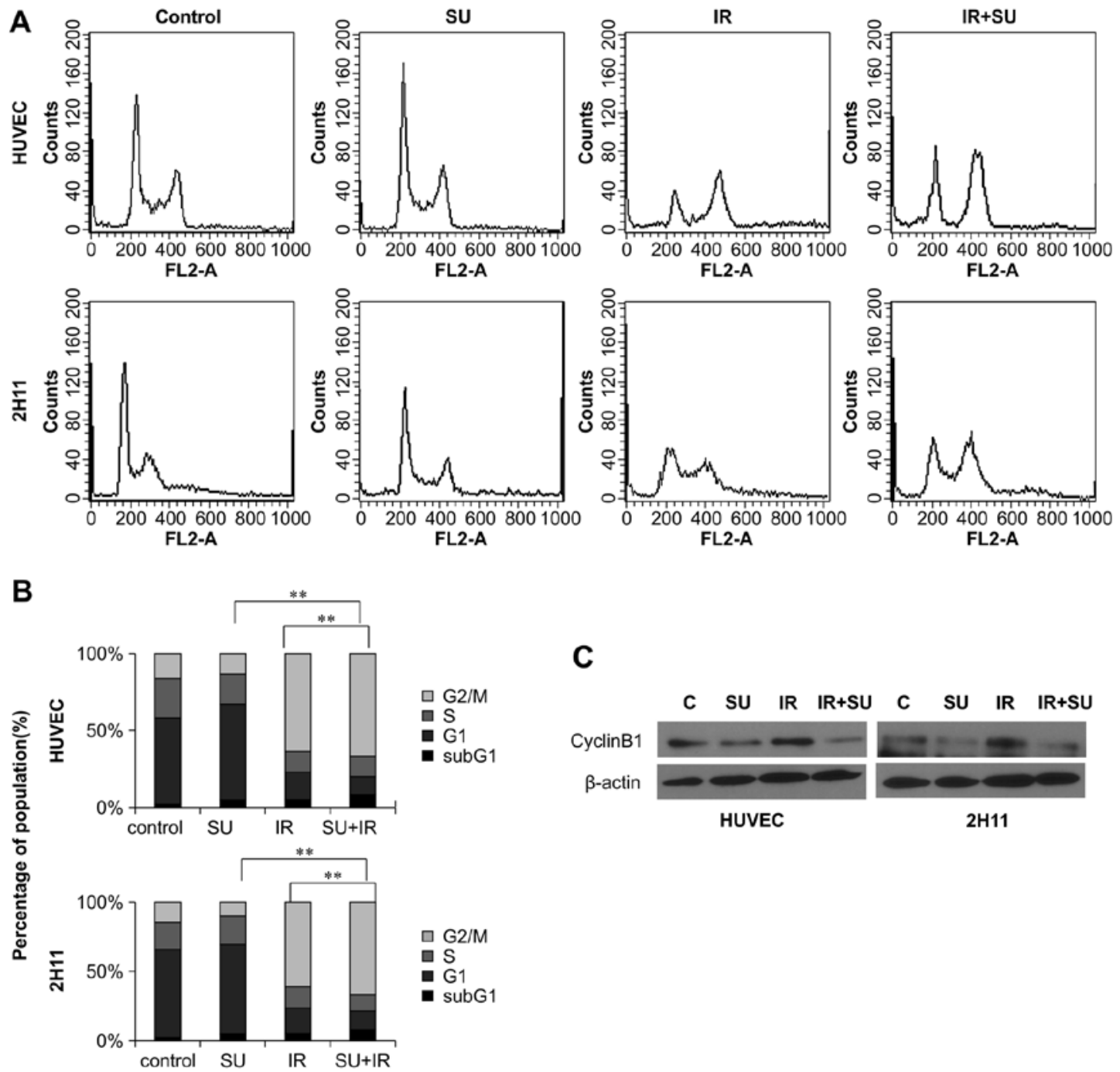

C

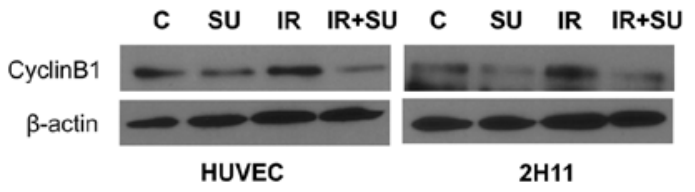

Figure 3. SU5416 blocks cell cycle progression in the G2-M phase of irradiated cells and modulates the expression of cell cycle regulators. (A and B) Human umbilical vein endothelial cells (HUVEC) and 2H11 cells were treated with combination of $1 \mu \mathrm{M}$ SU5416 and 5 Gy radiation. After 24 h, the cell cycle distribution was analyzed quantitatively. Values represent means of three experiments $\pm \mathrm{SE}$; ${ }^{*} \mathrm{p}<0.05$, ${ }^{* *} \mathrm{p}<0.001$. (C) Cyclin expression was analyzed by western blotting. HUVEC and $2 \mathrm{H} 11$ cells were treated with radiation before SU5416 and incubated for $24 \mathrm{~h}$. Equal amounts of cell lysates (30 $\mu \mathrm{g})$ were separated by electrophoresis and analyzed by western blotting as indicated.

Table III. REF and dose reduction values.

\begin{tabular}{lccc}
\hline Cell type & Radiation type & REF value & Dose reduction (\%) \\
\hline HUVEC & gamma-ray & 1.75 & 43 \\
2 H11 & gamma-ray & 1.59 & 38
\end{tabular}

HUVEC, human umbilical vein endothelial cells.

combined treatment with SU5416 and radiation (Fig. 3C). Western blotting showed that radiation alone showed an accumulation of cyclin B1 involved in the G2/M transition, whereas SU5416 alone reduced the expression of the regulator. In contrast, cyclin B1 expression was attenuated by $24 \mathrm{~h}$ of SU5416 treatment, regardless of the radiation dose (Fig. 3C).

Influence of SU5416 on radiation-induced DNA damage and DNA repair activity. We further evaluated the DNA damage response by analyzing the expression of the damage-responsive protein $\mathrm{H} 2 \mathrm{AX}$. Histone $\mathrm{H} 2 \mathrm{AX}$ is phosphorylated at $\mathrm{Ser}^{139}$ $(\gamma$-H2AX) in response to double-strand break (DSB) processing. As expected, SU5416-pretreated cells showed a higher level of ionizing radiation-induced $\gamma-\mathrm{H} 2 \mathrm{AX}$ (Fig. 4), since it is known that SU5416 increases ionizing radiation-induced DSB. The expression of $\gamma$-H2AX was consistently observed until $24 \mathrm{~h}$ after radiation exposure in the presence of SU5416. Both endothelial cells after the combined treatment with SU5416 and radiation showed damaged DNA foci, which appeared at $1 \mathrm{~h}$ after radiation exposure and remained even until $24 \mathrm{~h}$ (Fig. 4A). Furthermore, SU5416 treatment itself did not alter the induction or subsequent disappearance of foci at any time point examined.

Effects of SU5416 and radiation on mitogen-activated protein kinase (MAPK) expression in ECs. Members of the MAPK, ERK and JNK are well known to be involved in DNA damage responses $(26,27)$. We performed western blotting to assess the levels of the phosphorylated form of pro-survival marker ERK and the pro-apoptotic marker JNK (Fig. 5). The level 


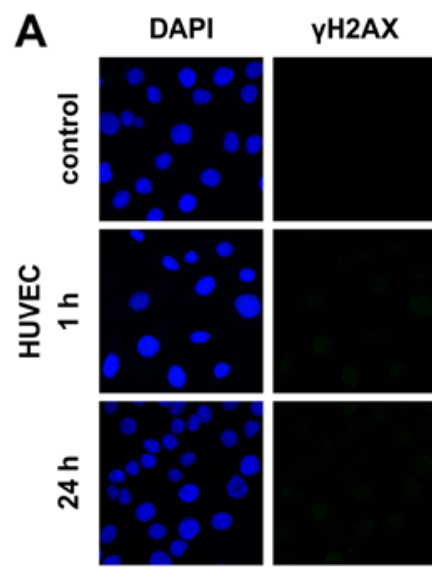

SU

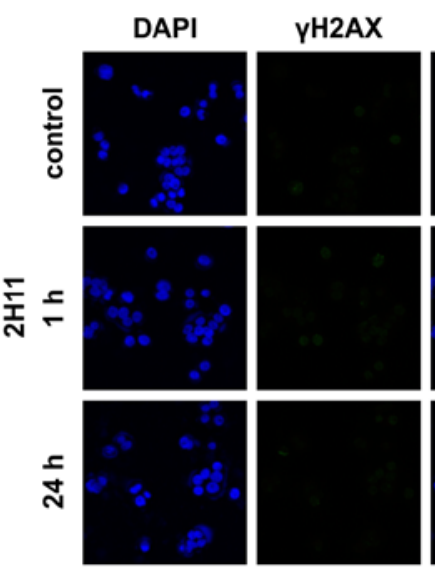

su

B

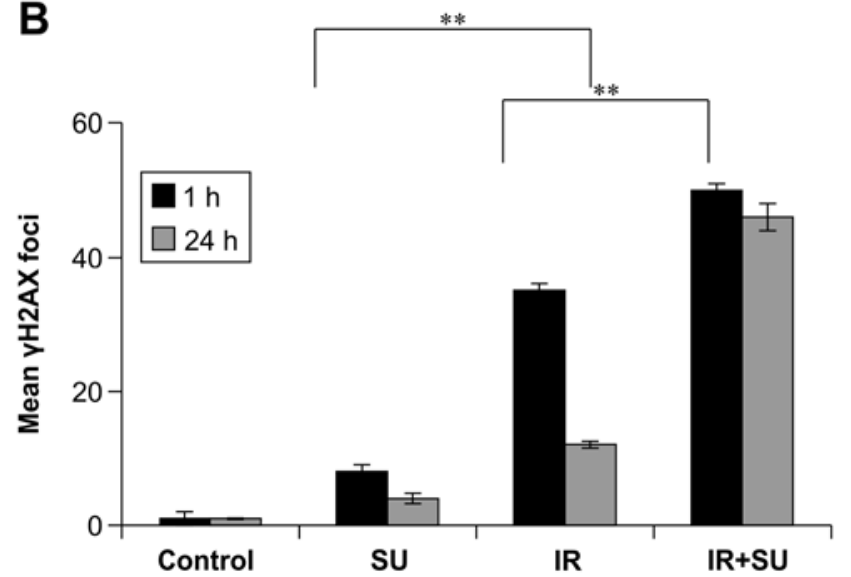

YH2AX
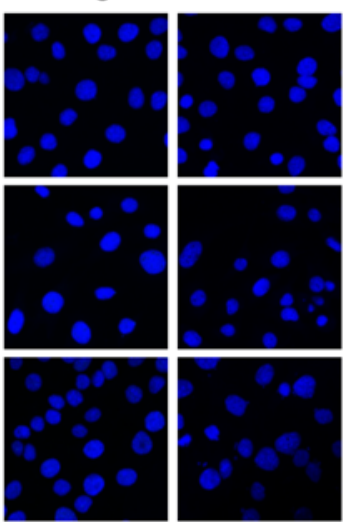

DAPI
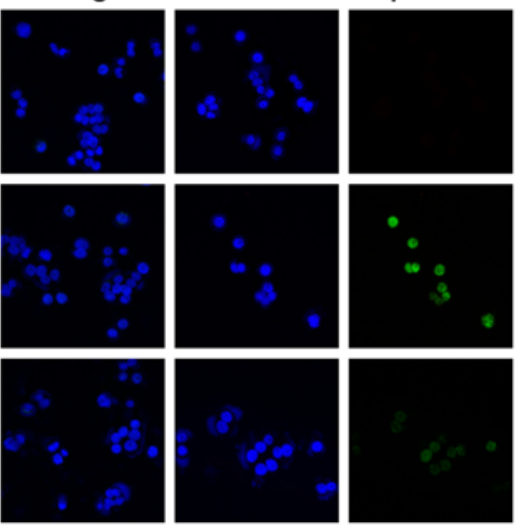

IR

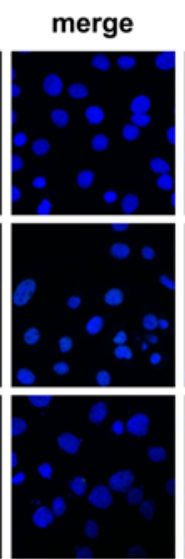

merge
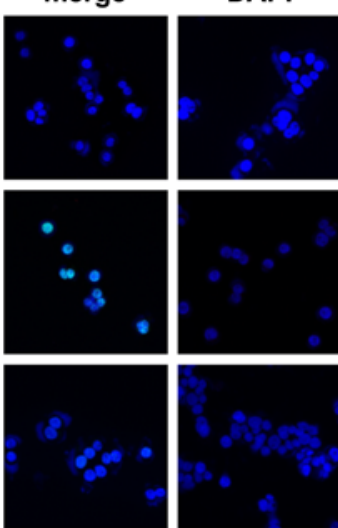

$y H 2 A X$

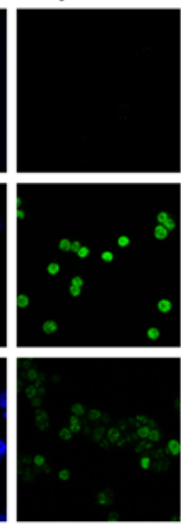

IR+SU

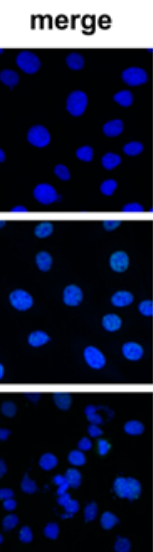

IR+SU

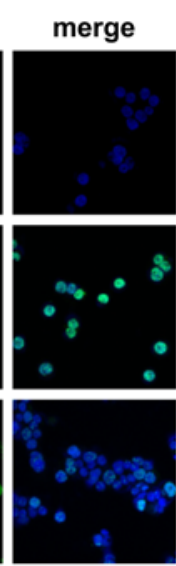

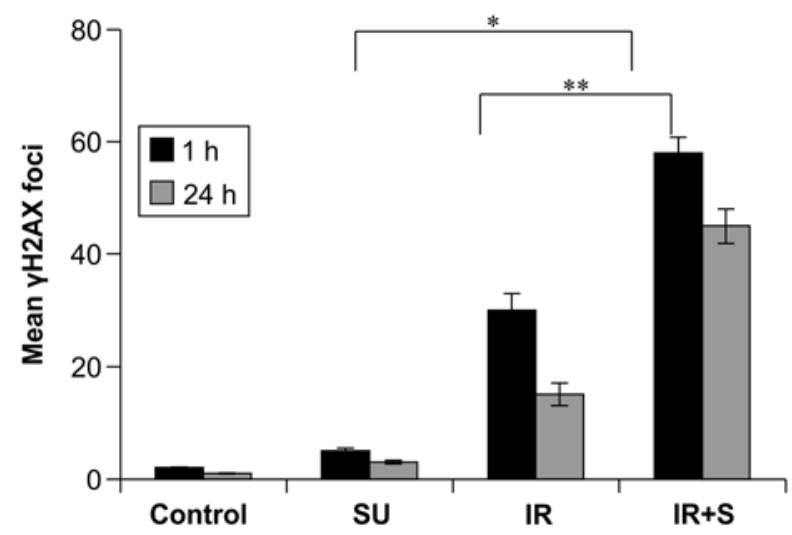

Figure 4. Effects of SU5416 on the DNA damage response in irradiated endothelial cells. (A and B) Immunocytochemistry staining for H2AX phosphorylation (Ser-139, green) in human umbilical vein endothelial cells (HUVEC) and 2H11 cells treated with radiation or SU5416 at various time-points. Values represent means of three experiments $\pm \mathrm{SE} ;{ }^{*} \mathrm{p}<0.05,{ }^{* *} \mathrm{p}<0.001$.

of p-ERK in IR irradiated cells was significantly increased, whereas, sharply decreased in the combination treatment cells.

Since the radioprotective response of ECs includes Akt activation $(28,29)$, we theorized that the enhanced irradiation-induced apoptosis observed in SU5416-treated ECs was caused by the inhibition of Akt activation. In line with this, an increase of the active phosphorylated form of Akt protein (p-Akt) was found in EC cells subjected to IR or SU5416 treatment; however, combination treatment reduced the level of the induced p-Akt (Fig. 5). This inhibition of p-Akt may be responsible for the radiosensitizing effects of SU5416 by enhancing the susceptibility of $\mathrm{G} 2 / \mathrm{M}$ arrested cells to undergo apoptosis in response to the IR induced DNA damage.

Effect of SU5416 and radiation on cell motility and cell invasion. We next evaluated the effects of SU5416 on the invasive and migratory capacities of endothelial cells using a scratch assay. Notably, compared with treatment with SU5416 or 
A

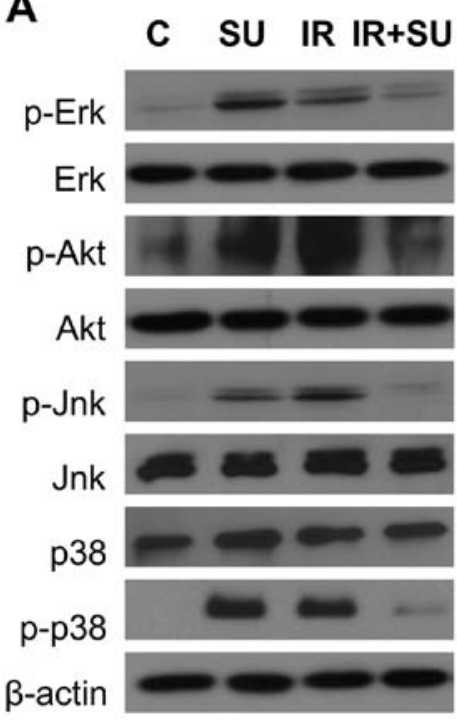

HUVEC
B

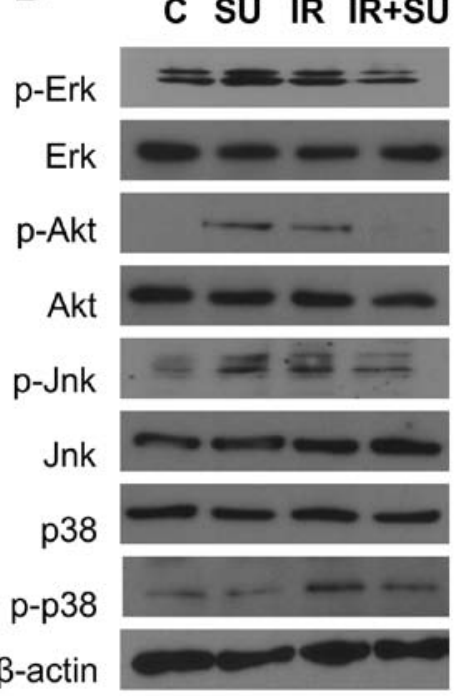

2H11

Figure 5. The expression of mitogen-activated protein kinases (MAPKs) with SU5416 and radiation of endothelial cells. (A and B) Whole cell lysates from each group were immunoblotted with the indicated antibodies in human umbilical vein endothelial cells (HUVEC) and 2H11 cells.
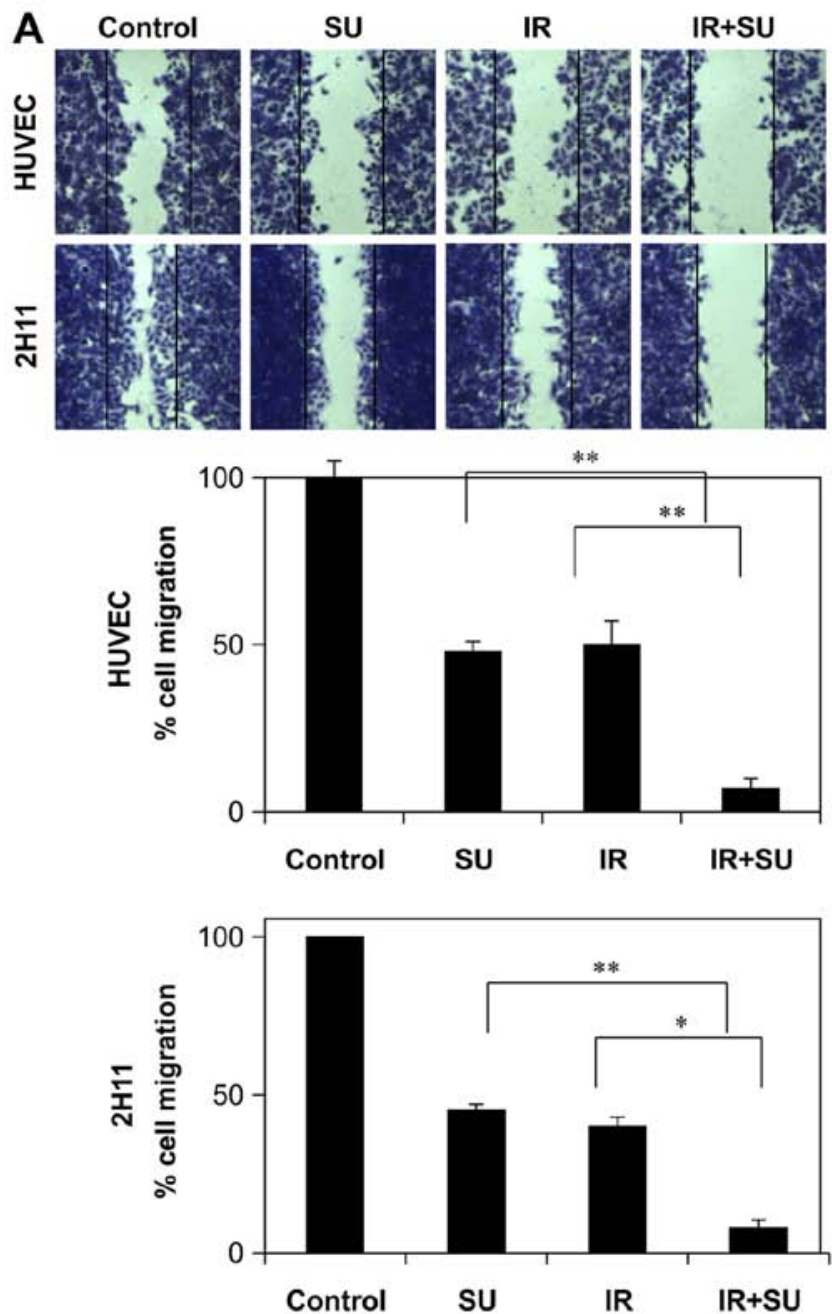

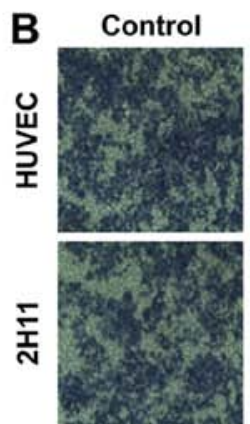

SU
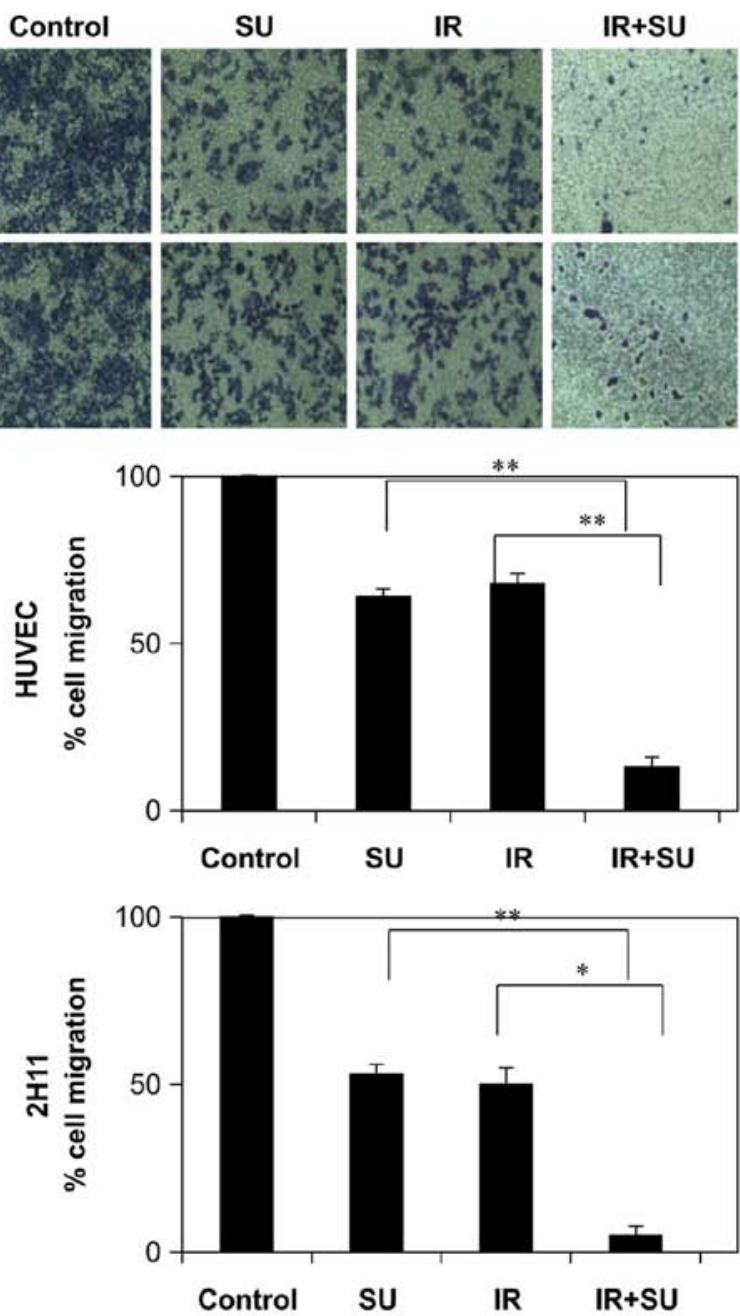

Figure 6. The effect of treatment with SU5416 and radiation on the invasion and migration of endothelial cells. (A) A wound was created in endothelial cells with a $200 \mu \mathrm{l}$ pipette tip for a scratch assay, and then treated with SU5416 and radiation. After incubation for $24 \mathrm{~h}$, the number of cells that migrated across the wound was counted. Each assay was photographed, the distance between the migrating cell edge was quantified, and percentage cell migration was calculated. Values represent means of three experiments $\pm \mathrm{SE} ;{ }^{*} \mathrm{p}<0.05$ and ${ }^{* *} \mathrm{p}<0.001$. (B) Endothelial cell invasion was examined by Matrigel invasion assay. The number of cells that had invaded through the Matrigel was counted in five high power fields. Values represent means of three experiments $\pm \mathrm{SE}$; ${ }^{*}<<0.05$ and ${ }^{* *} \mathrm{p}<0.001$. 
A

Control
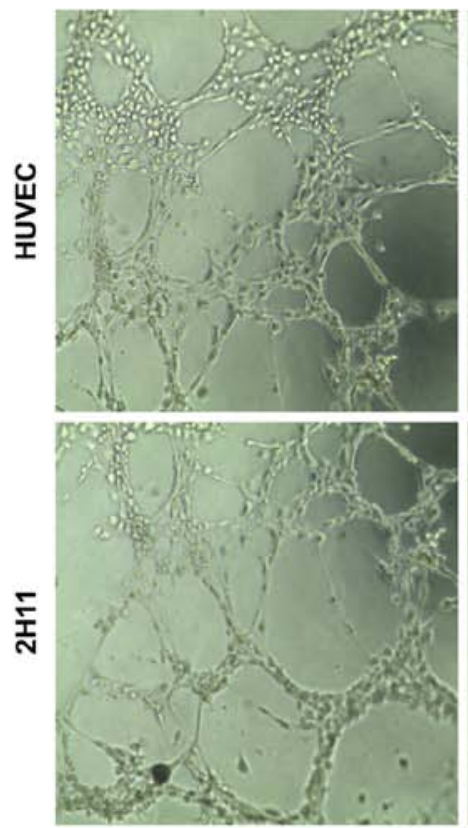

SU
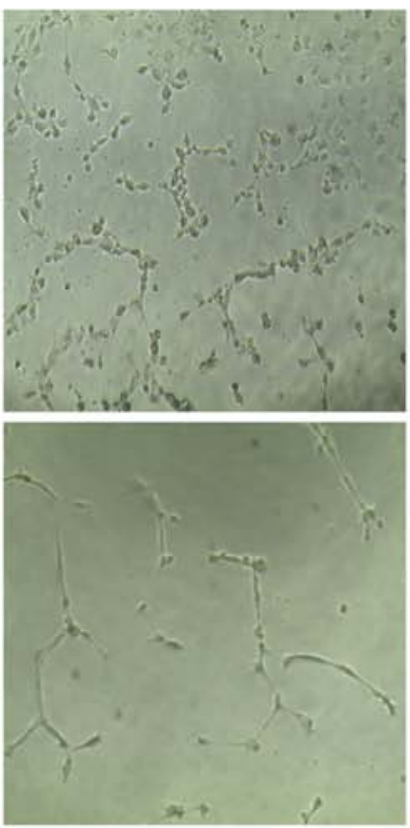

IR
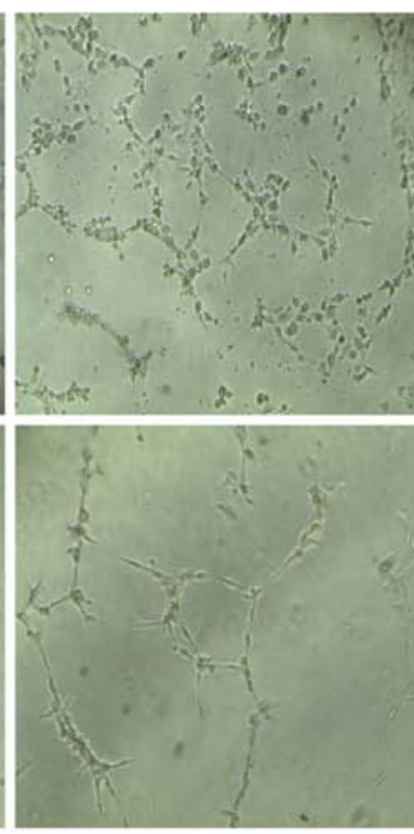

IR+SU

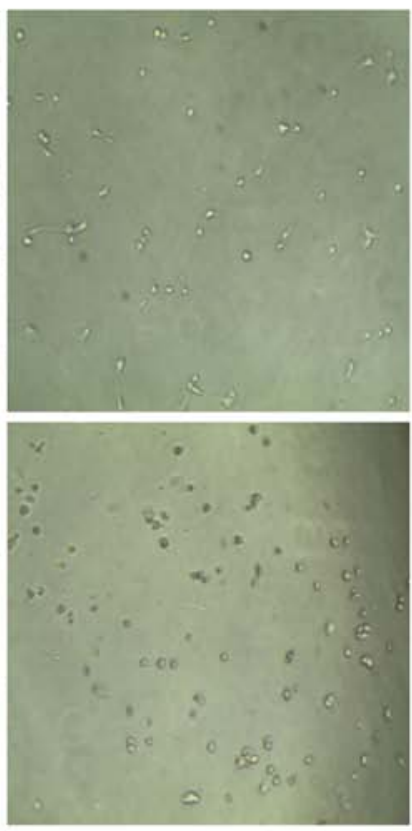

B

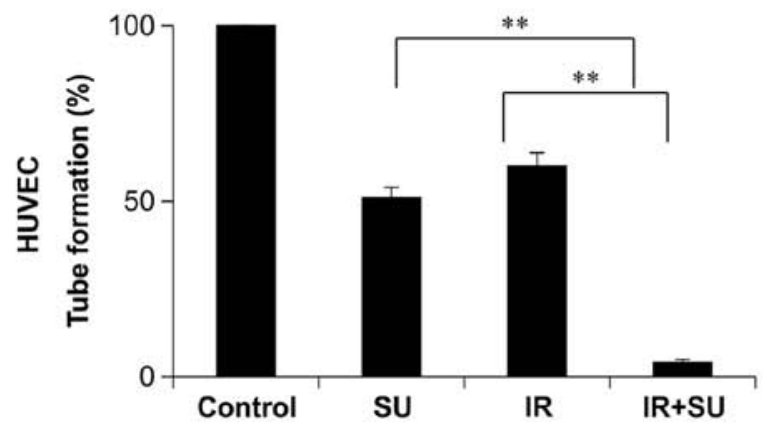

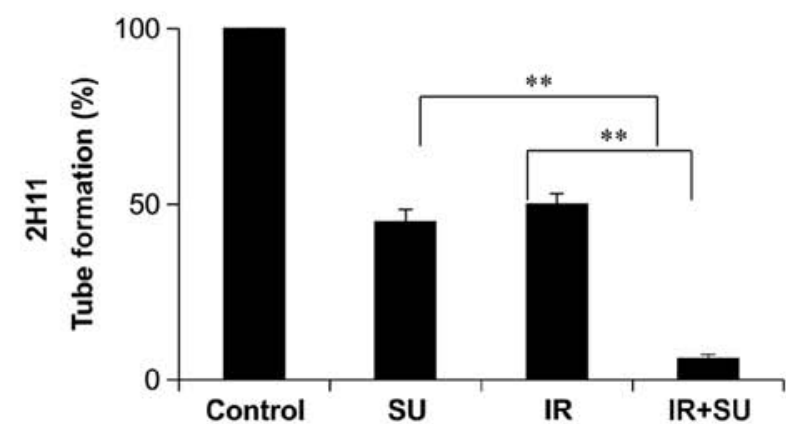

Figure 7. The effect of treatment with SU5416 and radiation on the angiogenesis of endothelial cells. (A) Representative photomicrographs of in vitro tube formation assay for control, SU5416, radiation and combination treatment. (B) Quantitative data for tube formation expressed as angiogenic score \pm SE from three independent experiments. ${ }^{*} \mathrm{p}<0.05$ and ${ }^{* *} \mathrm{p}<0.001$.

radiation alone, combination treatment significantly inhibited cell migration (Fig. 6A). We also performed Matrigel invasion assay to examine the effect of SU5416 combination treatment on tumor cell invasiveness and found that combination treatment was highly effective at inhibiting tumor cell invasion in both endothelial lines (Fig. 6B).

Combination treatment significantly inhibits angiogenesis. The production of tubular structures is another critical process in angiogenesis; therefore, we investigated the effects of SU5416 on HUVEC and 2H11 tube formation. SU5416 treatment not only quantitatively reduced the number of formed tubes in EC cultures, but also altered the morphology of the cells (Fig. 7). These effects were significantly greater in combination-treated cells as compared to each treatment alone, suggesting at least an additive inhibition of tube formation (Fig. 7).

\section{Discussion}

Combinations of radiotherapy with drugs are being investigated to enhance the cure rates and decrease side effects. In this regard, drugs with anti-angiogenic effects are of great interest. The importance of angiogenesis in the progression of human tumors has been presented by many outstanding academic studies describing the relationship between angiogenic tumor phenotypes and patient survival (30). These studies suggested that the number of microvessels in primary tumors possibly predict the prognosis of various tumors such as lung $(31,32)$, breast $(33,34)$, bladder (35) and colon (36) carcinomas, and in tumors of the oral cavity (37). Thus, control of angiogenesis has been identified as an critical approach for the therapeutic applications of human cancers $(38,39)$. The vascular endothelium is very resistant to the effects of radiation, so VEGF may cause enhanced resistance to radiation-induced damage (40). Therefore, preclinical studies propose that anti-angiogenic agents increase tumor control in response to radiation (6). Many such compounds are already in clinical studies or have been approved for the treatment of certain malignancies (41). However, it is still unclear which combinations of signaling inhibitors would be the most effective as an anticancer regimen and which of these would benefit from a combination with radiotherapy. In this context, we showed in ECs that 
the combination of VEGF signaling inhibition increases the anticancer effects of each monotherapy. We also found that radiotherapy in combination with VEGF signaling inhibition highly increases anti-angiogenic and antitumor effects of the respective drug therapies. In these studies, we used SU5416 as an inhibitor of VEGF signaling.

Recently, clinical studies have shown that the combination of SU5416 and radiation may offer clinical gains in patients with human cancer cell types (14); however, the mechanism underlying this effect appears to be somewhat more complex than that predicted in previous studies. Here, we provide a scientific rationale for the clinical application of SU5416 as a radiosensitizer in ECs. We have studied the various mechanisms by which SU5416 may increase the therapeutic efficacy of radiation by inhibiting tumor cell survival, cell cycle regulation, DNA repair activity, tumor cell invasiveness and angiogenesis in ECs.

Previous studies show that SU5416 combined with radiation significantly decrease the clonogenic survival abilities and enhance the radiosensitivity of ECs by activating apoptosis through PARP and caspase-3 (Figs. 1 and 2). When SU5416 was treated after radiation, ECs failed to undergo mitosis seemingly due to a block in transition from G2 to M phase that may result from the downregulation of cyclin B1 (Fig. 3). The irradiation of cells leads to electron scattering through the Compton effect, which subsequently causes DNA breaks (42). H2AX phosphorylation, a marker of DNA DSBs, was estimated as an indication of the radiation-induced DNA damage response (43-45). The results show that the combined treatment delayed the clearance of $\gamma-\mathrm{H} 2 \mathrm{AX}$, suggesting that SU5416 maintains DNA damage, thus increasing radiosensitivity (Fig. 4).

Migration of cancer cells is also a major event in metastatic cascade of cancers. Cell migration is a highly integrated process that is important for the growth of cancer cells in various organs of the body; therefore, we examined the effect of our combination therapy in inhibiting the migratory capacity of ECs. VEGF-2 expression plays an important role in cell migration by initiating many intracellular signaling pathways (46). Our data showed that decreases in VEGF-2 expression are associated with a decrease in the migratory potential of ECs following exposure to combination of SU5416 and radiation (Fig. 6). In ECs, ionizing radiation leads to phosphatidylinositol 3-kinase (PI3K)/Akt pathway activation that contributes to post-irradiation cell survival $(28,29)$. Some tumor-derived growth factors, particularly VEGF and basic fibroblast growth factor (bFGF), can enhance the radioresistance of ECs (47), but this can also occur through PI3K/Akt signaling (48). Inhibitors of PI3K, wortmannin, and LY294002, are well known to enhance the radiosensitivity of ECs (28); therefore, appropriate pharmacologic blockers of the PI3K/Akt pathway could be applied to radiosensitize the tumor vasculature. Akt is a pro-survival gene required for the $\mathrm{G} 2 / \mathrm{M}$ transition $(49,50)$, and oncogenic Akt can enhance the survival of cells after DNA damage by overcoming this checkpoint block, as well as the apoptosis induced by DNA damage (51). Recent evidence shows that many radiosensitizers possess anticancer effects through the inhibition of Akt (52), and VEGF is known as an important target of SU5416. VEGF dominantly acts on angiogenesis via the PI3K/Akt and MAPK signaling cascade (53). We observed that the VEGF2 phosphorylation raised by irradiation was downregulated by both combinations of SU5416 and radiation (Fig. 5). ERK is a key downstream component of the RAF/MEK/ERK signaling pathway and aberrant signaling through the ERK pathway was able to increase cell immortalization, proliferation and resistance to radiation (54). Western blot analysis demonstrated that radiation led to ERK activation, which was suppressed by the post-irradiation treatment of SU5416. Active form of Akt has been studied to indirectly inhibit JNK, a kinase known to control apoptosis (55). Consistent with previous studies, we observe that IR- and combination-treated EC cells show a negative correlation between p-Akt and p-JNK protein levels. ERK pathway activation is rescued with radioresistance (56), and the observable decrease in ERK activation after combination treatment likely sensitizes the cells to apoptosis. Our data are consistent with a model whereby combination treatment sensitizes the cells by relieving IR-induced resistance to apoptosis in ECs by first limiting the Akt survival pathway, and subsequently inducing JNK activation, thus committing the cells to an apoptotic fate. Moreover, VEGF treatment of endothelial cells significantly enhanced the tube formation on growth factor reduced Matrigel (Fig. 7). Our data demonstrate that SU5416 in combination treatment also inhibited VEGF-mediated endothelial cells tube formation (in vitro angiogenesis assay).

In conclusion, our investigation demonstrated that the anti-angiogenic compound SU5416 had an effective therapeutic radiosensitizing potential in endothelial cells. This radiosensitizing effect was associated with an inhibition of cell survival, cell cycle regulation, DNA repair activity, tumor cell invasiveness, and angiogenesis. We have provided evidence for the molecular basis of chemoradiation treatment; however, in vivo mouse model experiments should be carried out to minimize the possible complications in clinical applications. Furthermore, as the radiosensitizing effect of SU5416 in photon beam treatment is well known, it will be necessary to compare its sensitizing effect to proton or carbon beams in particle radiation to enhance the biological efficiency and safety of these forms of radiotherapy.

\section{Acknowledgements}

This study was supported by the National Research Foundation of Korea (NRF) funded by the Korean government (MSIP; no.NRF-2014R1A1A3053958,NRF2015R1A2A1A05001823).

\section{References}

1. Jubb AM, Pham TQ, Hanby AM, Frantz GD, Peale FV, Wu TD, Koeppen HW and Hillan KJ: Expression of vascular endothelial growth factor, hypoxia inducible factor $1 \alpha$, and carbonic anhydrase IX in human tumours. J Clin Pathol 57: 504-512, 2004.

2. Garcia-Barros M, Paris F, Cordon-Cardo C, Lyden D, Rafii S, Haimovitz-Friedman A, Fuks Z and Kolesnick R: Tumor response to radiotherapy regulated by endothelial cell apoptosis. Science 300: 1155-1159, 2003.

3. Huber PE, Bischof M, Jenne J, Heiland S, Peschke P, Saffrich R, Gröne HJ, Debus J, Lipson KE and Abdollahi A: Trimodal cancer treatment: Beneficial effects of combined antiangiogenesis, radiation, and chemotherapy. Cancer Res 65: 3643-3655, 2005.

4. Poggi MM, Coleman CN and Mitchell JB: Sensitizers and protectors of radiation and chemotherapy. Curr Probl Cancer 25: 334-411, 2001. 
5. Chan LW and Camphausen K: Angiogenic tumor markers, antiangiogenic agents and radiation therapy. Expert Rev Anticancer Ther 3: 357-366, 2003.

6. Wachsberger P, Burd R and Dicker AP: Tumor response to ionizing radiation combined with antiangiogenesis or vascular targeting agents: Exploring mechanisms of interaction. Clin Cancer Res 9: 1957-1971, 2003.

7. Gorski DH, Beckett MA, Jaskowiak NT, Calvin DP, Mauceri HJ, Salloum RM, Seetharam S, Koons A, Hari DM, Kufe DW, et al: Blockage of the vascular endothelial growth factor stress response increases the antitumor effects of ionizing radiation. Cancer Res 59: 3374-3378, 1999.

8. Lee CG, Heijn M, di Tomaso E, Griffon-Etienne G, Ancukiewicz M, Koike C, Park KR, Ferrara N, Jain RK, Suit HD, et al: Anti-vascular endothelial growth factor treatment augments tumor radiation response under normoxic or hypoxic conditions. Cancer Res 60: 5565-5570, 2000.

9. Geng L, Donnelly E, McMahon G, Lin PC, Sierra-Rivera E, Oshinka $\mathrm{H}$ and Hallahan DE: Inhibition of vascular endothelial growth factor receptor signaling leads to reversal of tumor resistance to radiotherapy. Cancer Res 61: 2413-2419, 2001.

10. Fong TA, Shawver LK, Sun L, Tang C, App H, Powell TJ Kim YH, Schreck R, Wang X, Risau W, et al: SU5416 is a potent and selective inhibitor of the vascular endothelial growth factor receptor (Flk-1/KDR) that inhibits tyrosine kinase catalysis, tumor vascularization, and growth of multiple tumor types. Cancer Res 59: 99-106, 1999.

11. Mendel DB, Laird AD, Smolich BD, Blake RA, Liang C Hannah AL, Shaheen RM, Ellis LM, Weitman S, Shawver LK, et al: Development of SU5416, a selective small molecule inhibitor of VEGF receptor tyrosine kinase activity, as an antiangiogenesis agent. Anticancer Drug Des 15: 29-41, 2000.

12. Peterson AC, Swiger S, Stadler WM, Medved M, Karczmar G and Gajewski TF: Phase II study of the Flk-1 tyrosine kinase inhibitor SU5416 in advanced melanoma. Clin Cancer Res 10 4048-4054, 2004.

13. Bäckman U, Svensson A and Christofferson R: Importance of vascular endothelial growth factor $\mathrm{A}$ in the progression of experimental neuroblastoma. Angiogenesis 5: 267-274, 2002

14. Timke C, Zieher H, Roth A, Hauser K, Lipson KE, Weber KJ, Debus J, Abdollahi A and Huber PE: Combination of vascular endothelial growth factor receptor/platelet-derived growth factor receptor inhibition markedly improves radiation tumor therapy. Clin Cancer Res 14: 2210-2219, 2008.

15. Abdollahi A, Lipson KE, Han X, Krempien R, Trinh T, Weber KJ Hahnfeldt P, Hlatky L, Debus J, Howlett AR, et al: SU5416 and SU6668 attenuate the angiogenic effects of radiation-induced tumor cell growth factor production and amplify the direct antiendothelial action of radiation in vitro. Cancer Res 63: 3755-3763, 2003.

16. Wachsberger PR, Burd R, Marero N, Daskalakis C, Ryan A, McCue P and Dicker AP: Effect of the tumor vascular-damaging agent, ZD6126, on the radioresponse of U87 glioblastoma. Clin Cancer Res 11: 835-842, 2005.

17. Ning S, Laird D, Cherrington JM and Knox SJ: The antiangiogenic agents SU5416 and SU6668 increase the antitumor effects of fractionated irradiation. Radiat Res 157: 45-51, 2002.

18. Griffin RJ, Williams BW, Wild R, Cherrington JM, Park H and Song CW: Simultaneous inhibition of the receptor kinase activity of vascular endothelial, fibroblast, and platelet-derived growth factors suppresses tumor growth and enhances tumor radiation response. Cancer Res 62: 1702-1706, 2002.

19. Lu B, Geng L, Musiek A, Tan J, Cao C, Donnelly E, McMahon G, Choy $\mathrm{H}$ and Hallahan DE: Broad spectrum receptor tyrosine kinase inhibitor, SU6668, sensitizes radiation via targeting survival pathway of vascular endothelium. Int J Radiat Oncol Biol Phys 58: 844-850, 2004.

20. Zips D, Eicheler W, Geyer P, Hessel F, Dörfler A, Thames HD Haberey $M$ and Baumann M: Enhanced susceptibility of irradiated tumor vessels to vascular endothelial growth factor receptor tyrosine kinase inhibition. Cancer Res 65: 5374-5379, 2005.

21. Edwards E, Geng L, Tan J, Onishko H, Donnelly E and Hallahan DE: Phosphatidylinositol 3-kinase/Akt signaling in the response of vascular endothelium to ionizing radiation. Cancer Res 62: 4671-4677, 2002.

22. Schueneman AJ, Himmelfarb E, Geng L, Tan J, Donnelly E, Mendel D, McMahon G and Hallahan DE: SU11248 maintenance therapy prevents tumor regrowth after fractionated irradiation of murine tumor models. Cancer Res 63: 4009-4016, 2003.
23. Krystal GW, Honsawek S, Kiewlich D, Liang C, Vasile S, Sun L, McMahon G and Lipson KE: Indolinone tyrosine kinase inhibitors block Kit activation and growth of small cell lung cancer cells. Cancer Res 61: 3660-3668, 2001.

24. Kumar P, Benedict R, Urzua F, Fischbach C, Mooney D and Polverini P: Combination treatment significantly enhances the efficacy of antitumor therapy by preferentially targeting angiogenesis. Lab Invest 85: 756-767, 2005.

25. Lea DE: Actions of Radiations on Living Cells. 2nd edition, Cambridge University Press, New York, NY, 1955.

26. Tang D, Wu D, Hirao A, Lahti JM, Liu L, Mazza B, Kidd VJ, Mak TW and Ingram AJ: ERK activation mediates cell cycle arrest and apoptosis after DNA damage independently of p53. J Biol Chem 277: 12710-12717, 2002.

27. Yang J, Yu Y and Duerksen-Hughes PJ: Protein kinases and their involvement in the cellular responses to genotoxic stress. Mutat Res 543: 31-58, 2003.

28. Kabakov AE, Makarova YM and Malyutina YV: Radiosensitization of human vascular endothelial cells through HSP90 inhibition with 17-N-allilamino-17-demethoxygeldanamycin. Int J Radiat Oncol Biol Phys 71: 858-865, 2008.

29. Tan J and Hallahan DE: Growth factor-independent activation of protein kinase $\mathrm{B}$ contributes to the inherent resistance of vascular endothelium to radiation-induced apoptotic response. Cancer Res 63: 7663-7667, 2003.

30. Cherrington JM, Strawn LM and Shawver LK: New paradigms for the treatment of cancer: The role of anti-angiogenesis agents. Adv Cancer Res 79: 1-38, 2000.

31. Fontanini G, De Laurentiis M, Vignati S, Chinè S, Lucchi M, Silvestri V, Mussi A, De Placido S, Tortora G, Bianco AR, et al: Evaluation of epidermal growth factor-related growth factors and receptors and of neoangiogenesis in completely resected stage I-IIIA non-small-cell lung cancer: Amphiregulin and microvessel count are independent prognostic indicators of survival. Clin Cancer Res 4: 241-249, 1998.

32. Kawaguchi T, Yamamoto S, Kudoh S, Goto K, Wakasa K and Sakurai M: Tumor angiogenesis as a major prognostic factor in stage I lung adenocarcinoma. Anticancer Res 17: 3743-3746, 1997.

33. Toi M, Hoshina S, Takayanagi $\mathrm{T}$ and Tominaga T: Association of vascular endothelial growth factor expression with tumor angiogenesis and with early relapse in primary breast cancer. Jpn J Cancer Res 85: 1045-1049, 1994.

34. Gasparini G and Harris AL: Clinical importance of the determination of tumor angiogenesis in breast carcinoma: Much more than a new prognostic tool. J Clin Oncol 13: 765-782, 1995.

35. Dickinson AJ, Fox SB, Persad RA, Hollyer J, Sibley GN and Harris AL: Quantification of angiogenesis as an independent predictor of prognosis in invasive bladder carcinomas. $\mathrm{Br} \mathrm{J}$ Urol 74: 762-766, 1994.

36. Takahashi Y, Kitadai Y, Bucana CD, Cleary KR and Ellis LM: Expression of vascular endothelial growth factor and its receptor, KDR, correlates with vascularity, metastasis, and proliferation of human colon cancer. Cancer Res 55: 3964-3968, 1995.

37. Williams JK, Carlson GW, Cohen C, Derose PB, Hunter S and Jurkiewicz MJ: Tumor angiogenesis as a prognostic factor in oral cavity tumors. Am J Surg 168: 373-380, 1994.

38. Ferrara N: Molecular and biological properties of vascular endothelial growth factor. J Mol Med Berl 77: 527-543, 1999.

39. Boehm-Viswanathan T: Is angiogenesis inhibition the Holy Grail of cancer therapy? Curr Opin Oncol 12: 89-94, 2000.

40. Brieger J, Kattwinkel J, Berres M, Gosepath J and Mann WJ: Impact of vascular endothelial growth factor release on radiation resistance. Oncol Rep 18: 1597-1601, 2007.

41. Jain RK, Duda DG, Clark JW and Loeffler JS: Lessons from phase III clinical trials on anti-VEGF therapy for cancer. Nat Clin Pract Oncol 3: 24-40, 2006.

42. Chapman JD and Gillespie CJ: Radiation-induced events and their time-scale in mammalian cells. Adv Radiat Biol 9: 143-198, 1981.

43. Rogakou EP, Pilch DR, Orr AH, Ivanova VS and Bonner WM: DNA double-stranded breaks induce histone H2AX phosphorylation on serine 139. J Biol Chem 273: 5858-5868, 1998.

44. Bonner WM, Redon CE, Dickey JS, Nakamura AJ, Sedelnikova OA, Solier S and Pommier Y: GammaH2AX and cancer. Nat Rev Cancer 8: 957-967, 2008.

45. Bourton EC, Plowman PN, Smith D, Arlett CF and Parris CN: Prolonged expression of the $\gamma-\mathrm{H} 2 \mathrm{AX}$ DNA repair biomarker correlates with excess acute and chronic toxicity from radiotherapy treatment. Int J Cancer 129: 2928-2934, 2011. 
46. Itokawa T, Nokihara H, Nishioka Y, Sone S, Iwamoto Y, Yamada Y, Cherrington J, McMahon G, Shibuya M, Kuwano M, et al: Antiangiogenic effect by SU5416 is partly attributable to inhibition of Flt-1 receptor signaling. Mol Cancer Ther 1: 295-302, 2002.

47. Peña LA, Fuks Z and Kolesnick RN: Radiation-induced apoptosis of endothelial cells in the murine central nervous system: Protection by fibroblast growth factor and sphingomyelinase deficiency. Cancer Res 60: 321-327, 2000.

48. Kumar P, Miller AI and Polverini PJ: p38 MAPK mediates gamma-irradiation-induced endothelial cell apoptosis, and vascular endothelial growth factor protects endothelial cells through the phosphoinositide 3-kinase-Akt-Bcl-2 pathway. J Bio Chem 279: 43352-43360, 2004.

49. Datta SR, Brunet A and Greenberg ME: Cellular survival: A play in three Akts. Genes Dev 13: 2905-2927, 1999.

50. Dangi S, Cha H and Shapiro P: Requirement for phosphatidylinositol-3 kinase activity during progression through $\mathrm{S}$-phase and entry into mitosis. Cell Signal 15: 667-675, 2003.

51. Kandel ES, Skeen J, Majewski N, Di Cristofano A, Pandolfi PP, Feliciano CS, Gartel A and Hay N: Activation of Akt/protein kinase B overcomes a $\mathrm{G}(2) / \mathrm{m}$ cell cycle checkpoint induced by DNA damage. Mol Cell Biol 22: 7831-7841, 2002.
52. Davies SP, Reddy H, Caivano M and Cohen P: Specificity and mechanism of action of some commonly used protein kinase inhibitors. Biochem J 351: 95-105, 2000.

53. Wilhelm SM, Carter C, Tang L, Wilkie D, McNabola A, Rong H, Chen C, Zhang X, Vincent P, McHugh M, et al: BAY 43-9006 exhibits broad spectrum oral antitumor activity and targets the RAF/MEK/ERK pathway and receptor tyrosine kinases involved in tumor progression and angiogenesis. Cancer Res 64: 7099-7109, 2004

54. Roberts PJ and Der CJ: Targeting the Raf-MEK-ERK mitogenactivated protein kinase cascade for the treatment of cancer. Oncogene 26: 3291-3310, 2007.

55. Figueroa $\mathrm{C}$, Tarras S, Taylor J and Vojtek AB: Akt2 negatively regulates assembly of the POSH-MLK-JNK signaling complex. J Biol Chem 278: 47922-47927, 2003.

56. Shonai T, Adachi M, Sakata K, Takekawa M, Endo T, Imai K and Hareyama M: MEK/ERK pathway protects ionizing radiationinduced loss of mitochondrial membrane potential and cell death in lymphocytic leukemia cells. Cell Death Differ 9: 963-971, 2002. 